\title{
Metode Analitycal Hierarchy Process untuk Menentukan Prioritas Penanganan J alan di Wilayah Balai Pemeliharaan J alan Mojokerto
}

\author{
Achmad Faiz Hadi P \\ Staf pengajar Program Studi Diploma Teknik Sipil FTSP ITS \\ Email : faiz@ce.its.ac.id
}

\begin{abstract}
ABSTRAK
J aringan jalan di Indonesia termasuk ruas jalan di Wilayah BPJ Mojokerto, merupakan salah satu penunjang kegiatan perekonomian yang bermuara pada peningkatan taraf hidup masyarakat. Untuk hal tersebut diperlukan layanan jaringan jalan yang mantap dan memadai, maka upaya penanganan jaringan jalan tersebut haruslah dilakukan terus menerus pada seluruh ruas jalan. Adanya kebijakan pendanaan, dan kebijakan lainnya berakibat semua ruas jalan tidak dapat tertangani seluruhnya, untuk itu dalam penyusunan program penanganan jalan harus menghasilkan urutan prioritas/ peringkat ruas-ruas jalan yang akan ditangani, maka diperlukan metode seleksi untuk menentukan peringkat/prioritas tersebut yang dapat menampung berbagai kebijakan dan permasalahan yang terjadi. Dalam tulisan ini metode seleksi yang digunakan adalah Analitycal Hierarchy Process Method. Untuk tujuan tersebut, diperlukan data-data eksisting ruas-ruas jalan dan data/informasi tentang kriteria penanganan jalan dari berbagai pihak di Bina Marga yang didapat melalui questionerquestioner. Hasil analisis menunjukkan pembobotan setiap elemen/kriteria harus dikalikan dengan bobot nilai kriteria yang sama yang dihasilkan dari data eksisting setiap ruas-ruas jalan, sehingga setiap ruas jalan akan mendapatkan skore dengan nilai angka tertinggi adalah mendapatkan prioritas pertama untuk ditangani dan akhirnya tersusun suatu daftar prioritas ruas-ruas jalan yang akan mendapatkan penanganan.
\end{abstract}

Kata kunci : Analitycal Hierarchy Process (AHP), quisioner, pembobotan

\section{PENDAhUluan}

Perkembangan perekonomian di Indonesia merupakan siklus proses produksi dan distribusi yang terjadi secara simultan dengan sektor lain, hal tersebut memerlukan prasarana pergerakan berupa jaringan jalan yang dapat melayani secara mantap dan memadai.

Untuk dapat mempertahankan atau meningkatkan pelayanan itu, seluruh ruas jalan - dalam hal ini ruas-ruas jalan di Wilayah BPJ Mojokerto, memerlukan penanganan/pemeliharaan jalan secara terus menerus baik rutin, berkala maupun peningkatan, maka disusun program penanganan sesuai dengan sasarannya antara lain meliputi kerusakan pada perkerasan jalan, kerusakan samping jalan, perbaikan prilaku berlalu lintas, juga memperhatikan pengaduan masyarakat/ publik komplain.
Keterbatasan pendanaan, dan adanya pertimbangan-pertimbangan lain, akan menyebabkan kendala tersendiri hingga semua ruas jalan tidak dapat tertangani seluruhnya ; maka dalam menyusun program penanganan harus berupa peringkat/prioritas ruas-ruas jalan yang akan ditangani, maka metode Analitycal Hierarchy Process diusulkan untuk menentukan peringkat/ prioritas dimaksud.

\section{METODE ANALYTICAL HIERARCHY PROCESS ( AHP )}

Metode Analytical Hierarchy Prosess atau Proses Hirarki Analitik, dikembangkan oleh Thomas L Saaty pada tahun 1986 ( Thomas L. Saaty 1986).

Dalam bahasan tentang Metode Proses Hierarki Analitik dalam tulisan ini diambil dari prinsip-prinsip dalam buku Thomas L Saaty tersebut. 
Proses Hirarki Analitik adalah suatu model yang luwes yang memungkinkan kita untuk mengambil keputusan dengan mengkombinasikan pertimbangan dan nilai pribadi secara logis, dapat menyusun skala baru untuk mengukur sifat-sifat yang telah terjadi.

a. Konsep Pokok

Untuk memahami dan menangani apa yang sedang terjadi disekitar kita, maka perlu memperbaiki ingatan kita terhadap peristiwa-peristiwa yang telah terjadi serta ketepatan pengetahuan kita dengan jalan meninjau semua fakta yang ada dan menyusun ke dalam sebuah kerangka yang logis, jika ingin mengambil sebuah keputusan yang rasional dan obyektif.

Sebetulnya kita membutuhkan cara berfikir yang sederhana bukannya yang lebih rumit, sehigga perlu adanya suatu kerangka yang memungkinkan untuk memikirkan masalah yang kompleks tetapi dengan cara yang sederhana.

Proses Hierarki Analitik dapat menyusun suatu perasaan serta institusi dan logika dalam suatu rancangan yang terstruktur untuk pengambilan keputusan dengan prinsip berfikir yang sederhana.

Ada 3 (tiga) prinsip dasar Proses Hierarki Analitik, yaitu antara lain :

1. Memecah-mecah persoalan menjadi unsur yang terpisah-pisah (elemen - elemen ) lalu menyusun secara hierarki.

2. Menetapkan prioritas atau peringkat terhadap elemenelemen tersebut menurut relatif pentingnya.

3. Menjamin bahwa semua elemen dikelompokkan secara logis dan diperingkatkan secara konsisten dengan kriteria yang logis.

b. Prinsip-prinsip Metode Proses Hirarki Analitik

Methode Analytical Hierarchy Prosess atau Proses Hirarki Analitik, dikembangkan oleh Thomas L Saaty pada th 1986 ( Thomas L. Saaty dalam bukunya Decision Making for Leaders, The Analitycal Hierarchy Process for Decision In Complex World ).

Proses Hirarki Analitik adalah suatu model yang luwes yang memungkinkan kita mengambil keputusan dengan mengkombinasikan pertimbangan dan nilai pribadi secara logis, dapat menyusun skala baru untuk mengukur sifat-sifat yang telah terjadi.

Prinsip-prinsip dasar dari Proses Hierarki Analitik dapat dijelaskan sebagai berikut.

Tiga (3) prinsip dasar dalam Proses Hirarki Analitik, antara lain :

1. Memecah-mecah persoalan dan menyusun secara hierarki.

Yaitu persoalan yang kompleks dipecah-pecah menjadi unsur yang terpisah-pisah, Ialu menyusun secara hierakis.

2. Penetapan Prioritas.

Elemen-elemen yang disusun secara hierarkis ditentukan prioritasnya dengan mensintesis pertimbangan kita terhadap elemen-elemen menurut relative pentingnya atau yang lebih disukai.

Untuk hal tersebut kita harus melakukan perbandingan berpasang antara elemen-elemen tersebut dan melakukan suatu pembobotan dan penjumlahan untuk mengahasilkan satu bilangan tunggal yang menunjukkan prioritas setiap elemen dimaksud.

\section{Konsistensi Logis}

Konsistensi logis diperlukan dalam menetapkan prioritas untuk elemen-elemen agar memperoleh hasil yang akurat dalam dunia nyata. Prosedur Hierarki Analitik ini mengukur konsistensi secara menyeluruh dari berbagai pertimbangan kita dengan Rasio Konsistensi nilainya maksimum harus $10 \%$ atau kurang. 
Konsistensi ada 2 hal penting yaitu:
a. Bahwa obyek serupa dikelompokkan secara homogenitas atau secara relevansinya. Contoh Kelengkeng dengan klerek.
b. Didasarkan pada kriteria tertentu, yang saling membedakan secara logis. Contoh : Tembaga dua kali lebih lunak dari pada besi, Timah tiga kali lebih lunak dari pada tembaga, berarti Timah enam kali lebih lunak dari pada Besi.

\section{MENENTUKAN DAN PEMBOBOTAN KRITERIA}

Salah satu prinsip AHP adalah menyusun realitas yang kompleks ke dalam bagianbagian (elemen-elemen) pokok, kemudian bagian ini dibagi menjadi elemen-elemen yang lebih kecil dan seterusnya lalu disusun kembali secara hirarki, elemenelemen tersebut dijadikan suatu kriteria dan sub kriteria.

Hirarki Tingkat I adalah fokus yang merupakan tujuan menyeluruh dari sistem ini, untuk Tingkat II adalah sebagai kriteria, sedangkan Tingkat III merupakan sub kriteria dari kriteria Tingkat II, Hirarki tersebut dapat digambarkan seperti dibawah ini.

Untuk menentukan bobot dari masingmasing elemen-elemen atau kriteria dan sub kriteria tersebut, maka disusun suatu questioner yang isinya pilihan tingkat pentingnya suatu kriteria dan sub-kriteria tersebut diatas dan disebarkan kepada bebarapa responden yaitu meliputi :

1. Dinas PU Bina Marga Propinsi Jawa Timur ( 15 Orang)

2. Proyek Pembangunan Jalan dan J embatan J awa Timur ( 10 orang )

3. Proyek Pemeliharaan Jalan dan J embatan J awa Timur ( 5 Orang )

4. Balai Pemeliharaan Jalan wilayah Moj okerto ( 10 Orang )

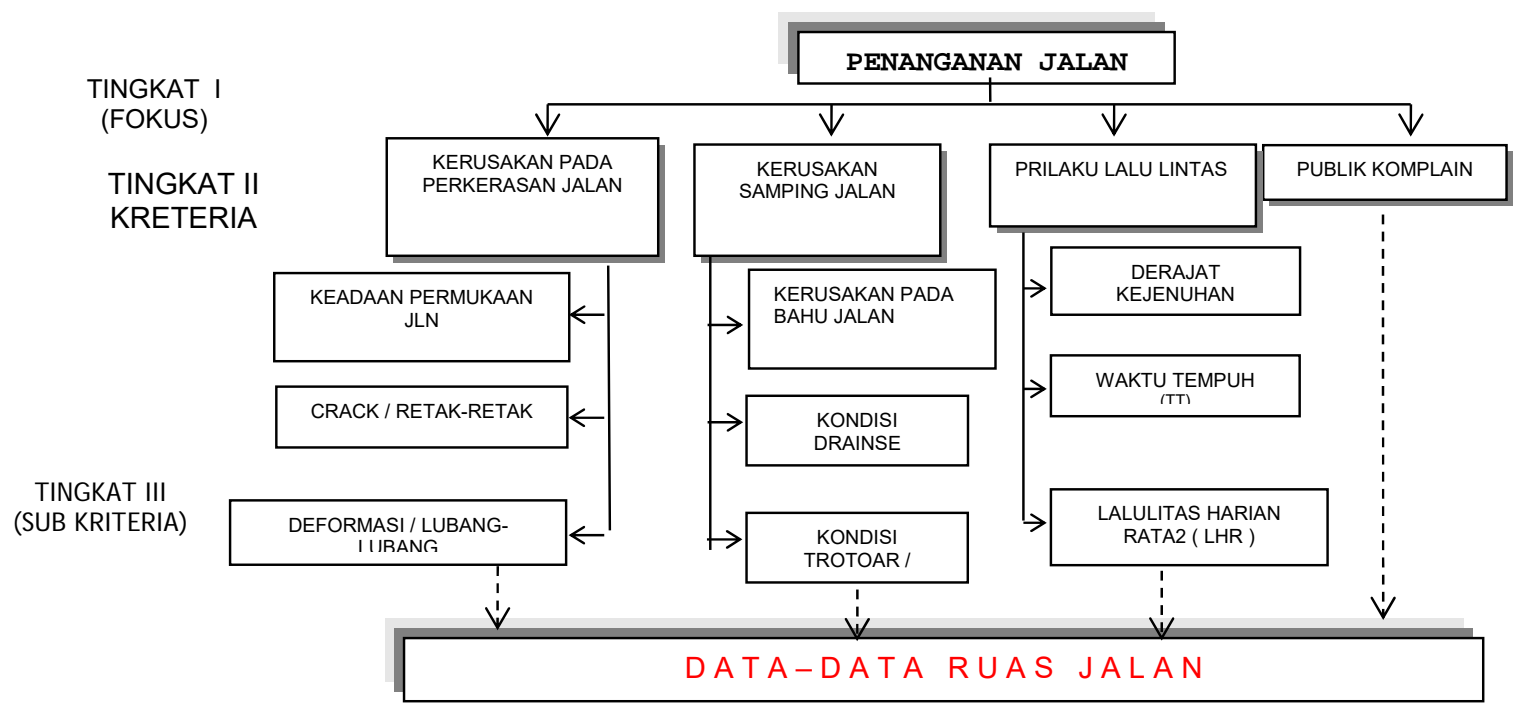

Gambar 1. Hirarki untuk menentukan prioritas 
Tabel 1 : Daftar Bobot dari Kriteria dan sub kriteria, hasil analisis elemen-elemen dalam metode Proses Hirarki Analitik.

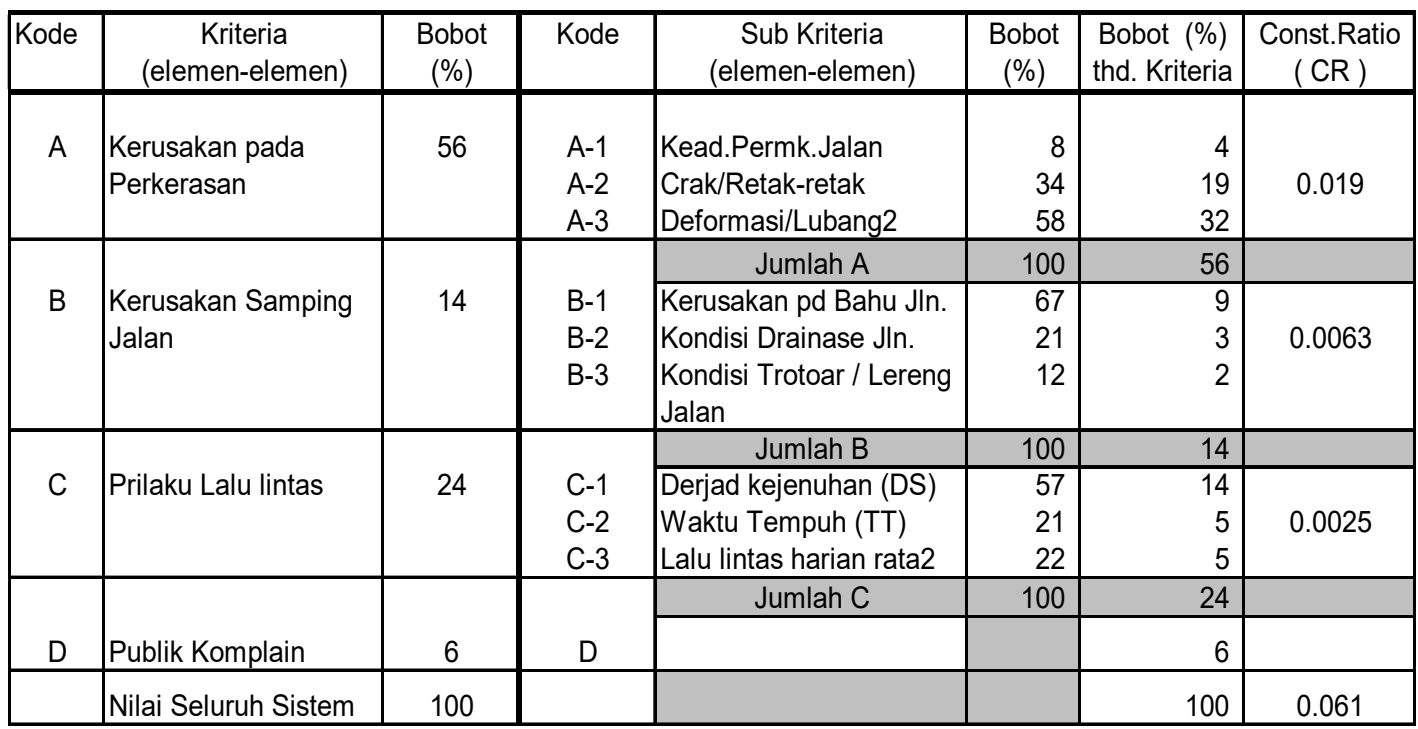

Data-data yang didapat dari responden merupakan hasil perbandingan secara berpasangan antara elemen-elemen dan menunjukkan intensitas pentingnya antara elemen-elemen yang satu dengan yang lainnya, lalu dari 40 buah data tersebut dirata-rata secara sederhana, dan selanjutnya dilakukan analisis untuk mengahasilkan nilai bobot setiap elemen/ kriteria dan sub-kriteria.

Untuk konsistensi data hasil questioner tersebut perlu dilakukan uji konsistensi, maka secara umum hasilnya dinyatakan konsisten karena nilai consistensi ratio (CR) lebih kecil dari $10 \%(<0.1)$.

Sedangkan hasil pembobotan dari kriteria dan sub-sub kriteria adalah seperti tercantum pada tabel 1 .

\section{KASUS RUAS JALAN DI WILAYAH BPJ MOJ OKERTO}

Untuk ruas-ruas jalan di Wilayah BPJ Mojokerto tersebut harus dicari data-data existing meliputi panjang segmen/ruas jalan, kerusakan pada samping jalan, prilaku lalu lintas yang terdiri dari nilai DS, TT dan LHR serta publik komplain.

\section{A. Kerusakan pada Perkerasan J alan}

Kerusakan pada perkerasan Jalan terdiri dari data Keadaan Permukaan Jalan,
Crack/ Retak-retak dan Deformasi/ Lubanglubang pada perkerasan jalan.

Data kondisi perkerasan tersebut ditunjukkan dengan suatu index kerusakan, dimana jika tidak ada kerusakan atau kondisi baik indexnya $=1$ untuk kondisi sedang index $=2$, rusak ringan index $=3$ dan untuk rusak berat index $=4$.

Untuk mendapatkan bobot index-index setiap ruas jalan diperoleh dengan rumusan sebagai berikut :

$\mathrm{NA}-1=(\underline{\mathrm{L} 1}$ *index $1+\mathrm{L} 2 *$ index $2+\mathrm{L} 3 * i n d e x$ $3+\mathrm{L} 4$ *index 4$) \times 100 \%$.

$\mathrm{L} *$ index max

$\mathrm{NA}-2=(\mathrm{L} 1 *$ index $1+\mathrm{L} 2 *$ index $2+\mathrm{L} 3 * i n d e x$ $3+\mathrm{L} 4$ *index 4$) \times 100 \%$.

$\mathrm{L} *$ index max

NA-3 $=$. ( L $1 * i n d e x ~ 1+L 2 * i n d e x ~ 2+$ L3*index 3+L4*index 4 ) $\times 100 \%$.

$\mathrm{L} *$ index $\max$

Dimana :

NA-1 : bobot nilai index untuk permukaan jalan.

NA-2 : bobot nilai index untuk Crack/ Retak-retak.

NA-3 : bobot nilai untuk Deformasi/ Lubang-lubang

L1 : panjang segmen pada index $=1$

L2 : panjang segmen pada index $=2$

L3 : panjang segmen pada index $=3$

Selengkapnya lihat Tabel 2. 


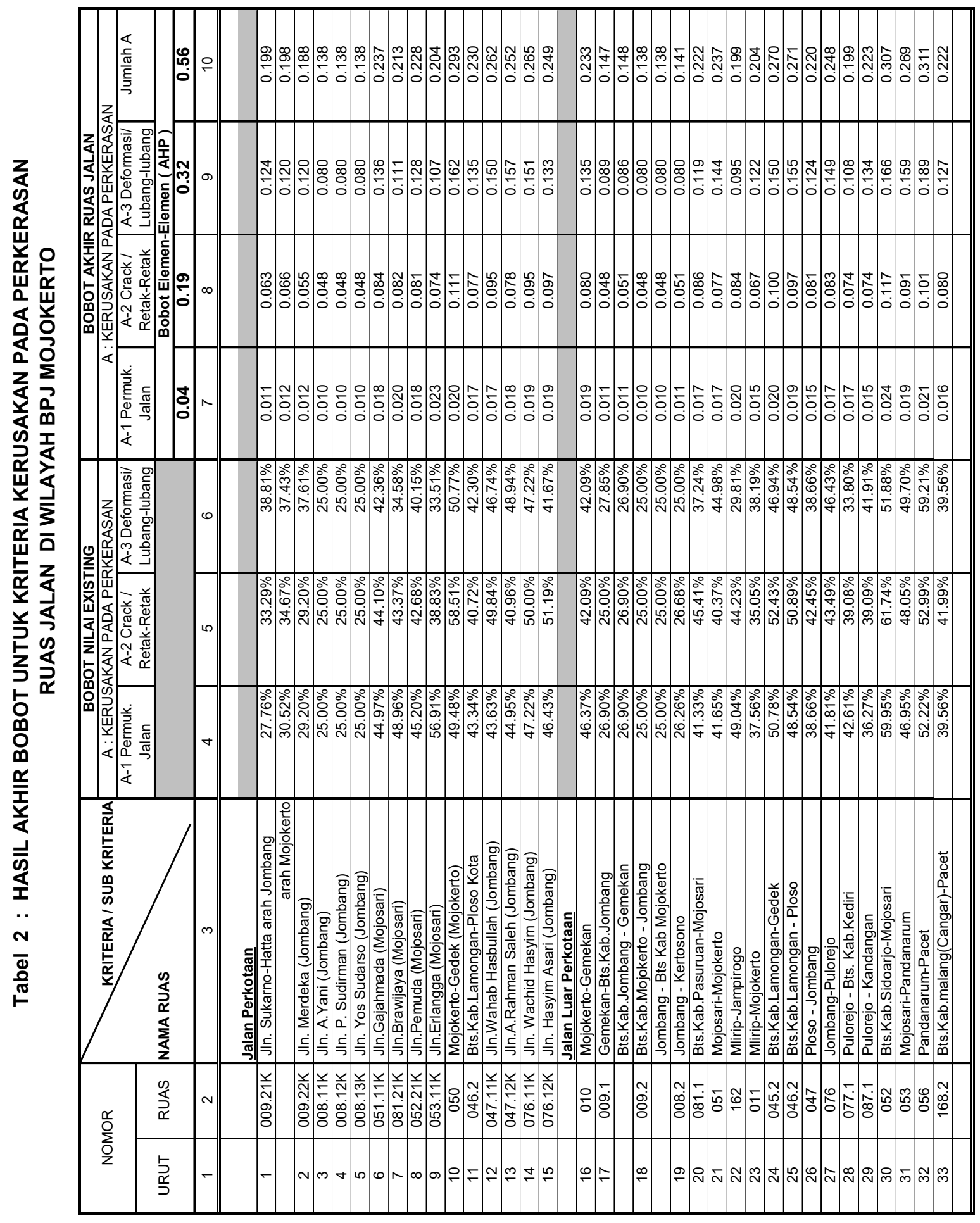


B. Kerusakan pada Samping J alan.

Kerusakan pada samping jalan ini terdiri dari sub-kriteria kerusakan pada bahu jalan, kondisi drainase jalan dan kondisi trotoar/lereng jalan.

B-1 Kerusakan pada Bahu Jalan

Perumusannya sebagai berikut :

$\mathrm{Nb}-1$ (kanan) $=(\mathrm{L} 1 * i n d e x ~ 1+\mathrm{L} 2 *$ index 2

+ L3*index 3) $\times 100 \%$

L*Index max

$\mathrm{Nb}-1$ (kiri) $=(\underline{\mathrm{L} 1 * \text { index } 1+\mathrm{L} 2 * \text { index } 2}$ $+\mathrm{L} 3 *$ index 3$) \times 100 \%$

L*Index max

$\mathrm{Nb}-1=(\mathrm{Nb}-1$ kanan $+\mathrm{Nb}-1$ kiri $) / 2$

Dimana :

$\mathrm{Nb}-1$ bobot/ nilai kuantitatif bahu jalan rata-rata kanan / kiri

L1 : panjang segmen pada index $=1$

L2: panjang segmen pada index $=2$

L3 : panjang segmen pada index $=3$ dan

$\mathrm{L}$ : panjang segmen jalan.

B-2 Kondisi Drainase Jalan.

Drainase tidak berfungsi diberikan nilai maksimum (100\%), jika berfungsi dengan baik diberikan nilai 0 (nol).

B-3 Kondisi Trotoar/ Lereng / alan. Bila konstruksi trotoar tersebut cukup aman untuk pejalan kaki diberi nilai $0 \%$ dan sebaliknya bila konstruksi trotoar tidak aman atau rusak atau beralih fungsi, maka mendapat nilai maksimum ( $100 \%$ ). Untuk ruas jalan luar kota biasanya tidak ada trotoarnya ditinjau pada lereng bahu jalan, bila terjadi longsoran jelas akan membahayakan pengguna jalan, maka diberi nilai maksimum ( $100 \%$ ) dan sebaliknya bila tidak ada kerusakan/longsoran nilainya adalah minimum ( $0 \%$ ). Selengkapnya lihat tabel 3.

C. Prilaku Lalu Lintas

Kriteria ini terdiri dari sub kriteria derajad kejenuhan (DS), kecepatan kendaraan (FV) dan waktu tempuh (TT), perhitungannya menggunakan metode kapasitas jalan perkotaan dan kapasitas jalan luar kota berdasarkan
Form UR-1, UR-2 dan UR-3 dalam buku MKJ I 1977 yang diterbitkan oleh Departemen PU.

\section{C-1 Derajad Kejenuhan ( DS)}

Diasumsikan bahwa untuk nilai DS $\geq$ 0.85 akan mendapatkan nilai maksimum (100 \%), maka untuk segmen/ruas jalan yang nilai DS < (lebih kecil) 0.85 dapat dirumuskan sebagai berikut.

NC-1 $=(n$ DS $/ 0.85) \times 100 \%$

Dimana :

NC-1 : nilai bobot DS

n DS : nilai DS pada segmen jalan.

\section{C-2 Pembobotan Nilai Waktu Tempuh} (TT)

Ruas jalan perkotaan kecepatan maksimum didasarkan pada kecepatan arus bebas dasar rata-rata untuk ruas jalan perkotaan tabel B-1:1 buku MKJ I 1977 ( 4/2D atau 2/1 ) yaitu = 55 $\mathrm{km} / \mathrm{jam}$ atau waktu tempuh 1.09 menit/ Km, sedangkan untuk ruas jalan luar kota kecepatan arus bebas dasar rata-rata didasarkan tabel B-1:1 jalan luar kota (4/2D) pada alinyemen datar yaitu $=70 \mathrm{~km} / \mathrm{jam}$ atau waktu tempuh $\mathrm{TT}=0.86 \mathrm{menit} / \mathrm{Km}$.

Pembobotannya untuk kecepatan maximum punya nilai $0 \%$ dan nilai maximum diasumsikan bila terjadi angka kecepatannya 2 kali lipat atau dengan rumusan sbb. :

NC-2 $=\{($ TTn-TTmin $) / T T \min \} * 100 \%$

C-3 Pembobotan Nilai Lalu Lintas Harian Rata-Rata (LHR)

Bobot nilai LHR maximum adalah diambil dari angka LHR maksimum, atau dapat dirumuskan sebagai berikut:

NC-3 $=($ LHR / LHR max $) \times 100 \%$

Contoh : hasil perhitungan pada ruas jalan Sukarno-Hatta J ombang, Link $009.21 \mathrm{~K}$ adalah:

Bobot nilai $A-1=27,76 \% ; \quad A-2=33,29 \%$ dan $\mathrm{A}-3=38,81 \%$ Bobot Nilai B-1 $=33 \%$; B-2 $=0 ; \quad B-3=0$ Bobot Nilai C-1 $=54 \%$ $\mathrm{C}-2=31 \%$ dan $\mathrm{C}-3=31 \%$ Bobot nilai $\mathrm{D}=0$ $\%$ Selengkapnya lihat tabel 4. 


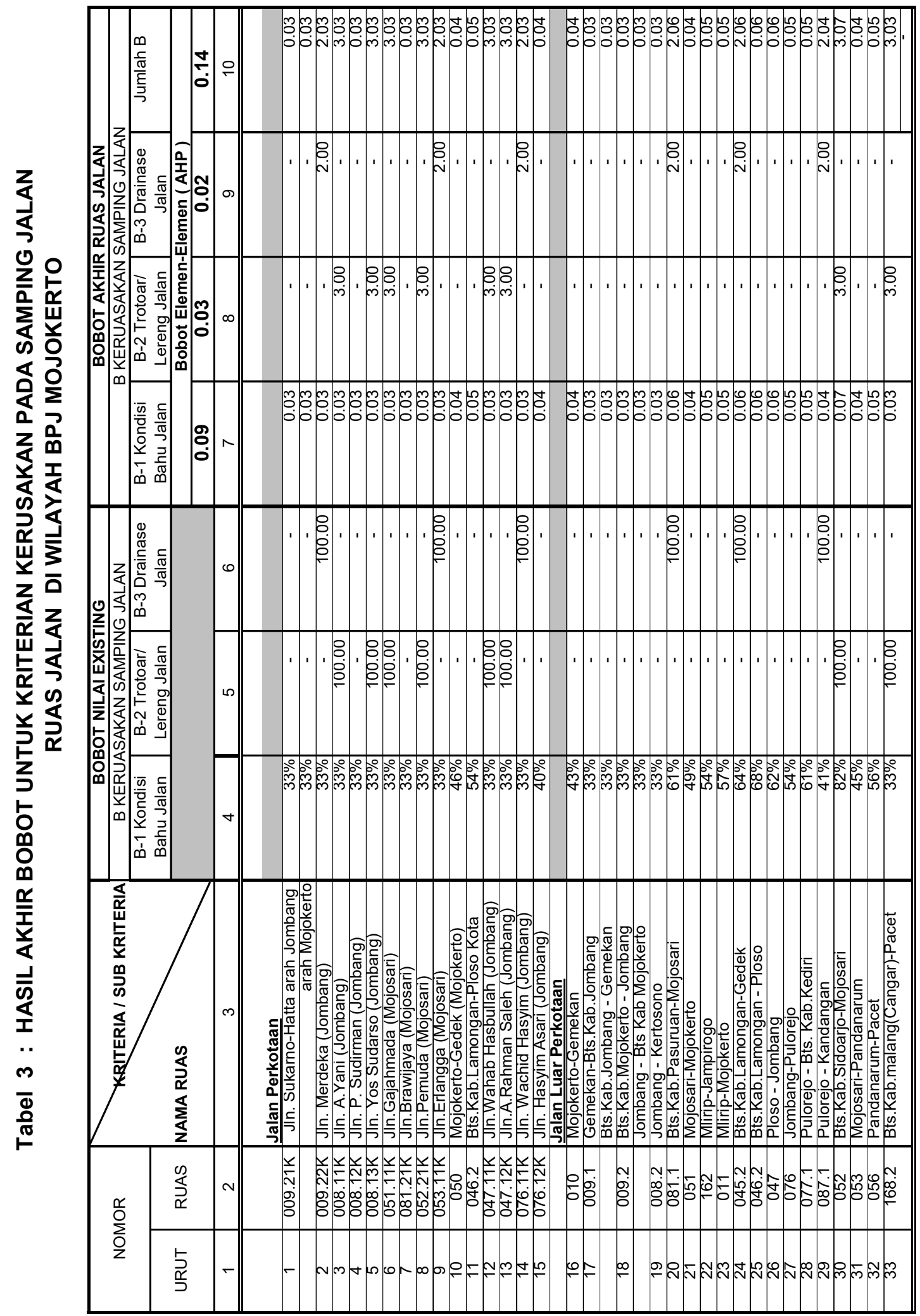




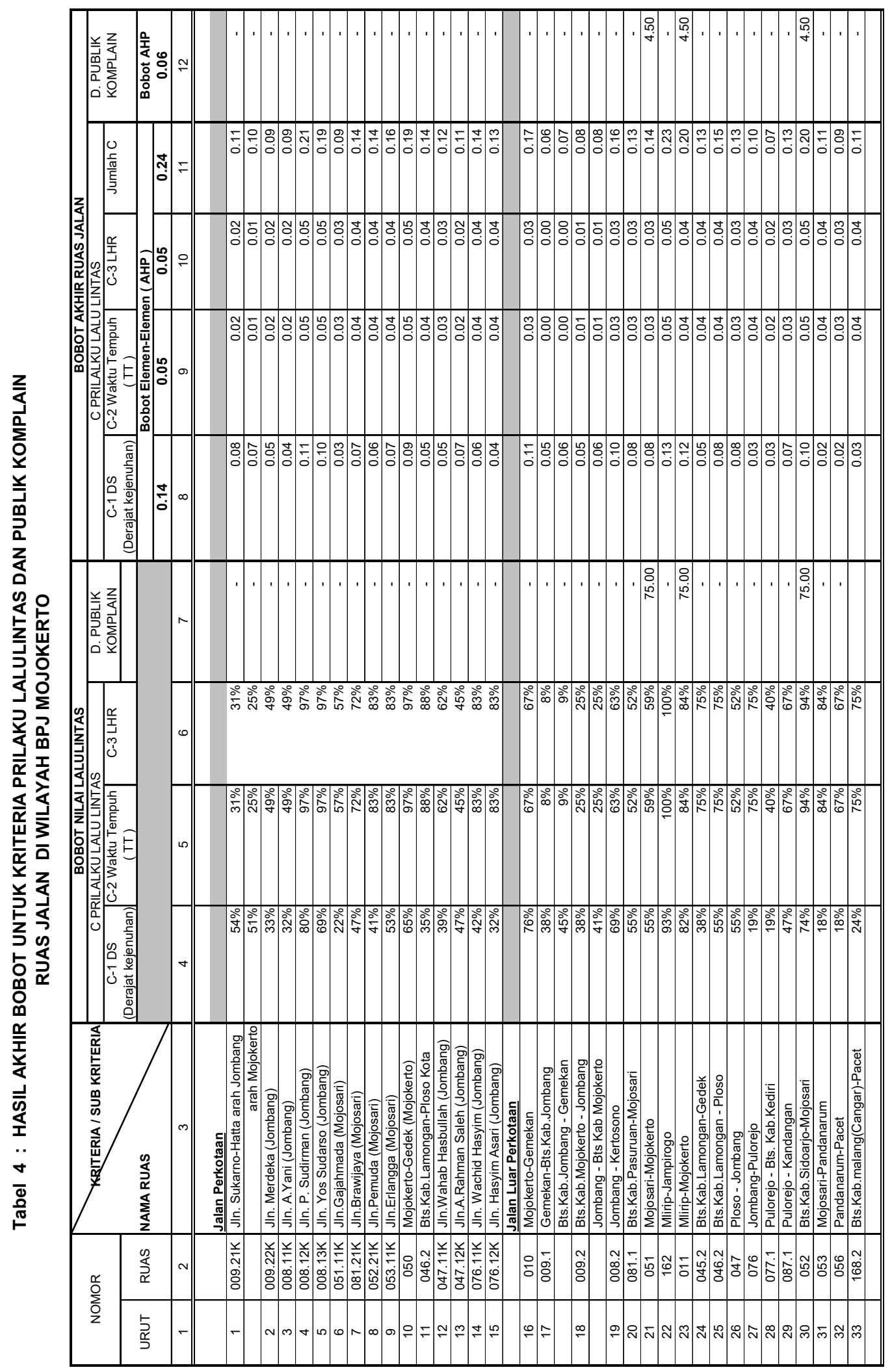




\section{ISSN. 1907-753X}

\section{PRIORITAS/PERINGKAT}

\section{J ALAN}

Dari hasil pembobotan nilai existing masingmasing ruas jalan tersebut diatas harus dikalikan dengan bobot yang diperoleh dari AHP, dimana suatu ruas jalan yang mempunyai nilai tertinggi adalah ruas $j$ alan yang memperoleh prioritas penanganan yang pertama, dan seterusnya.

Misalnya pada ruas jalan Sukarno Hatta J ombang, Link 009.21K

Bobot :

$A-1=27,76 \% \times 0,004=0,0011$;

$A-2=33,29 \% \times 0,19=0,063$ dan

$\mathrm{A}-3=38,81 \% \times 0,32=0,124$

jumlahnya $=0,199$.

Bobot :

$\mathrm{B}-1=33 \% \times 0,09=0,03$

$\mathrm{B}-2=0 \% \times 0,03=0$; jumlahnya $=0,03$

Bobot :

C-1 $=54 \% \times 0,14=0,08$;

$\mathrm{C}-2=31 \% \times 0,05=0,02$;

$\mathrm{C}-3=31 \% \times 0,05=0,02$

Total $=0,12$

Bobot : $\mathrm{D}=0 \%$ (tidak terjadi komplain dari masyarakat).

Angka 0,$004 ; 0,19 ; 0,32 ; 0,03 ; 0,08$ dan seterusnya dari tabel 1 yaitu diperoleh dari metode AHP, maka Bobot ruas jalan ( Link 009.21K ) adalah 0,199+0,03+0,12+0= 0,34 .

Hasil analisis tersebut seperti pada Tabel 5 dan Tabel 6. 
Tabel 5 : HASIL AKHIR BOBOT PADA SETIAP RUAS RUAS JALAN DI WILAYAH BPJ MOJOKERTO

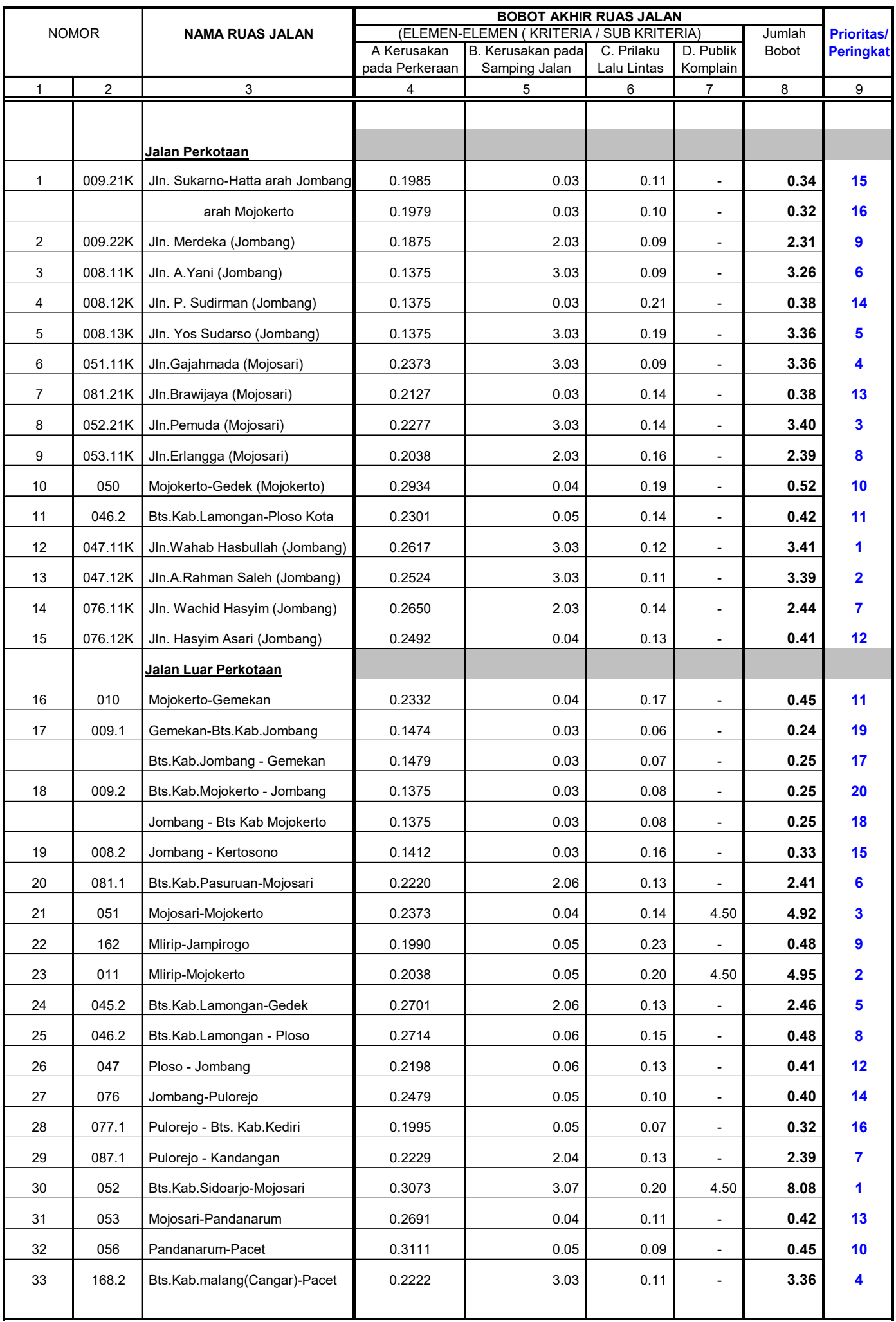


ISSN.1907-753X

TABEL : 6 URUTAN PRIORITAS DAN JENIS PENANGANAN JALAN UNTUK RUAS JALAN DIWILAYAH BPJ MOJOKERTO

\begin{tabular}{|c|c|c|c|c|c|c|}
\hline \multicolumn{2}{|c|}{ NOMOR } & \multirow{2}{*}{$\begin{array}{c}\text { NAMA RUAS JALAN } \\
3 \\
\end{array}$} & \multirow{2}{*}{$\begin{array}{c}\text { Jumlah } \\
\text { Bobot } \\
4 \\
\end{array}$} & \multirow{2}{*}{$\begin{array}{c}\text { Prioritas/ } \\
\text { Peringkat } \\
5 \\
\end{array}$} & \multirow{2}{*}{$\begin{array}{c}\text { Derajad } \\
\text { Kejenuhan } \\
\text { DS } \\
\end{array}$} & \multirow{2}{*}{$\begin{array}{c}\begin{array}{c}\text { Jenis } \\
\text { Penanganan }\end{array} \\
6 \\
\end{array}$} \\
\hline 1 & 2 & & & & & \\
\hline & & Jalan Perkotaan & & & & \\
\hline 1 & $047.11 \mathrm{~K}$ & Jln.Wahab Hasbullah (Jombang) & 3.38 & 1 & 0.33 & Pemel Berkala \\
\hline 2 & $047.12 \mathrm{~K}$ & Jln.A.Rahman Saleh (Jombang) & 3.37 & 2 & 0.4 & Pemel Berkala \\
\hline 3 & $052.21 \mathrm{~K}$ & Jln.Pemuda (Mojosari) & 3.36 & 3 & 0.35 & Pemel Berkala \\
\hline 4 & $051.11 \mathrm{~K}$ & Jln.Gajahmada (Mojosari) & 3.33 & 4 & 0.19 & Pemel Berkala \\
\hline 5 & $076.11 \mathrm{~K}$ & Jln. Wachid Hasyim (Jombang) & 2.40 & 5 & 0.36 & Pemel Berkala \\
\hline 6 & $009.22 \mathrm{~K}$ & Jln. Merdeka (Jombang) & 2.29 & 6 & 0.28 & Pemel Berkala \\
\hline 7 & 050 & Mojokerto-Gedek (Mojokerto) & 0.47 & 7 & 0.55 & Pemel Berkala \\
\hline 8 & 046.2 & Bts.Kab.Lamongan-Ploso Kota & 0.37 & 8 & 0.3 & Pemel Berkala \\
\hline 9 & $076.12 \mathrm{~K}$ & Jln. Hasyim Asari (Jombang) & 0.37 & 9 & 0.27 & Pemel Berkala \\
\hline 10 & $009.21 \mathrm{~K}$ & Jln. Sukarno-Hatta arah Jombang & 0.32 & 10 & 0.46 & Pemel Berkala \\
\hline \multirow[t]{2}{*}{11} & $009.21 \mathrm{~K}$ & Jln. Sukarno-Hatta arah Mojokerto & 0.31 & 11 & 0.43 & Pemel Berkala \\
\hline & & Jalan Luar Perkotaan & & & & \\
\hline 12 & 052 & Bts.Kab.Sidoarjo-Mojosari & 11.76 & 1 & 0.63 & Pemel Berkala \\
\hline 13 & 011 & Mlirip-Mojokerto & 8.66 & 2 & 0.6 & Pemel Berkala \\
\hline 14 & 051 & Mojosari-Mojokerto & 8.61 & 3 & 0.47 & Pemel Berkala \\
\hline 15 & 168.2 & Bts.Kab.malang(Cangar)-Pacet & 3.32 & 4 & 0.2 & Pemel Berkala \\
\hline 16 & 045.2 & Bts.Kab.Lamongan-Gedek & 2.42 & 5 & 0.32 & Pemel Berkala \\
\hline 17 & 081.1 & Bts.Kab.Pasuruan-Mojosari & 2.38 & 6 & 0.47 & Pemel Berkala \\
\hline 18 & 087.1 & Pulorejo - Kandangan & 2.36 & 7 & 0.4 & Pemel Berkala \\
\hline 19 & 046.2 & Bts.Kab.Lamongan - Ploso & 0.45 & 8 & 0.47 & Pemel Berkala \\
\hline 20 & 162 & Mlirip-Jampirogo & 0.43 & 9 & 0.79 & B / Pelebaran \\
\hline 21 & 056 & Pandanarum-Pacet & 0.42 & 10 & 0.15 & Pemel Berkala \\
\hline 22 & 010 & Mojokerto-Gemekan & 0.41 & 11 & 0.65 & Pemel Berkala \\
\hline 23 & 047 & Ploso - Jombang & 0.38 & 12 & 0.47 & Pemel Berkala \\
\hline 24 & 053 & Mojosari-Pandanarum & 0.38 & 13 & 0.15 & Pemel Berkala \\
\hline 25 & 076 & Jombang-Pulorejo & 0.36 & 14 & 0.16 & Pemel Berkala \\
\hline 26 & 077.1 & Pulorejo - Bts. Kab.Kediri & 0.30 & 15 & 0.16 & Pemel Berkala \\
\hline & & & & & & \\
\hline
\end{tabular}

Keterangan

Untuk nilai DS mendekati 0.85 dilakukan Pelebaran Jalan

J urnal APLIKASI: Media Informasi \& Komunikasi Aplikasi Teknik Sipil Terkini 


\section{KESIMPULAN}

Dari berbagai pembahasan maka dapat ditarik kesimpulan antara lain :

1. Bahwa Metode Analitycal Hierarchy Process adalah dapat dipergunakan untuk menentukan urutan/prioritas ruas-ruas jalan yang akan mendapatkan penanganan.

Metode ini adalah membagi persoalan pokok menjadi 4 elemen yang merupakan kriteria-kriteria penanganan jalan. Kriteria yang memperoleh intensitas pentingnya/prioritas paling tinggi adalah "Kerusakan pada Perkerasan Jalan" yaitu $56 \%$ hal ini didukung dengan sub-kriteria "Crack/Retak-retak (19 \%) dan Deformasi/Lubang-lubang (32\%) yang mana bila kedua sub-kriteria tersebut terjadi maka ruas jalan tersebut harus mendapat penanganan segera. Sedangkan untuk kriteria "Prilaku Lalu lintas" bobot tingkat pentingnya adalah pada posisi kedua yaitu $24 \%$ ini karena terdapat sub-kriteria Derajad kejenuhan (14\%). Untuk Kriteria "Kerusakan pada samping jalan" dan "Publik Komplain" walaupun ada sedikit pengaruhnya, dianggap kurang penting terhadap penyebab penanganan jalan sehingga mendapatkan bobot $14 \%$ dan $6 \%$

2. Telah dihasilkan daftar peringkat/ urutan prioritas ruas-ruas jalan di Wilayah BPJ Mojokerto. Sebagai contoh prioritas penanganan dengan peringkat 1-3, adalah sebagai berikut:

J alan Perkotaan
a. Jalan Wahab Hasbullah (J ombang)
b. Jalan A. Rahman Saleh (J ombang)
c. Jalan Pemuda (Mojosari)

Jalan Luar Perkotaan :

a. Ruas Jalan Batas Kabupaten Sidoarjo - Mojosari

b. Ruas J alan Mlirip - Mojokerto

c. Ruas J alan Mojosari - Mojokerto

Dari analisa kapasitas jalan menunjukkan bahwa rata-rata kapasitas jalan masih mencukupi, hanya satu ruas jalan yang mempunyai kapasitas mendekati jenuh ( $D S=0,79$ ) yaitu ruas jalan Mlirip-J ampirogo, sehingga perlu tindakan penanganan peningkatan/ pelebaran. Ruas jalan yang memperoleh peringkat/urutan prioritas pertama adalah JI. Wahab Hasbullah Jombang untuk Jalan Perkotaan, dan Ruas Jalan Gempol-Mojosari untuk ruas jalan luar kota.

\section{DAFTAR ACUAN}

Direktorat Jenderal Bina Marga. 1977, Manual Kapasitas Jalan Indonesia MKJI , Jakarta : Direktorat Bina Jalan Kota, Direktorat J enderal Bina Marga.

Menteri Kimpraswil. 2004. SK Nomor 376 tentang Penetapan Ruas-Ruas Jalan menurut Statusnya sebagai Jalan Nasional. Jakarta: Departemen Kimpraswil;

Peraturan Pemerintah Republik Indonesia Nomor 26 Tahun 1985, tentang Jalan, J akarta: Departemen Pekerjaan Umum.

Road Improvement Project II. 1998. Provisional Routine Maintenance Management System. Jakarta: Dirjen Bina Marga Departemen PU.

Saaty, Thomas L.1986. Pengambilan Keputusan bagi para Pemimpin, Proses Hirarki Analitik untuk Pengambil Keputusan dalam situasi Kompleks, Terjemahan oleh Setiono, Liana. 1993. Jakarta: PT. Pustaka Binaman Pressindo.

Undang-Undang Republik Indonesia, Nomor 13 Tahun 1980, tentang J alan, J akarta: Depatemen PU. 